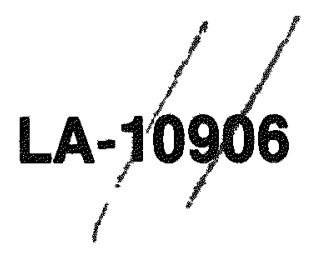

Penturt 0811

JUN 221987

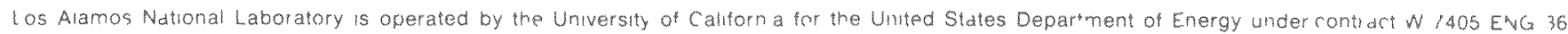

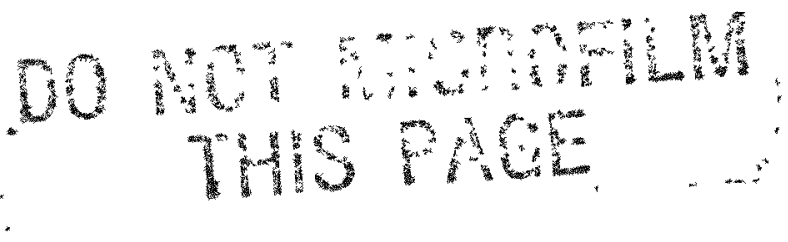

Improved Recovery and Purification
of Plutonium at Los Alamos Using Macroporous Anion Exchange Resin 


\section{DISCLAIMER}

This report was prepared as an account of work sponsored by an agency of the United States Government. Neither the United States Government nor any agency Thereof, nor any of their employees, makes any warranty, express or implied, or assumes any legal liability or responsibility for the accuracy, completeness, or usefulness of any information, apparatus, product, or process disclosed, or represents that its use would not infringe privately owned rights. Reference herein to any specific commercial product, process, or service by trade name, trademark, manufacturer, or otherwise does not necessarily constitute or imply its endorsement, recommendation, or favoring by the United States Government or any agency thereof. The views and opinions of authors expressed herein do not necessarily state or reflect those of the United States Government or any agency thereof. 


\section{DISCLAIMER}

Portions of this document may be illegible in electronic image products. Images are produced from the best available original document. 
This work was supported by the US Department of Energy, Office of Nuclear Materials Production.

\section{Edited by Mary J. Mann}

This report was submitted on November 26, 1986.

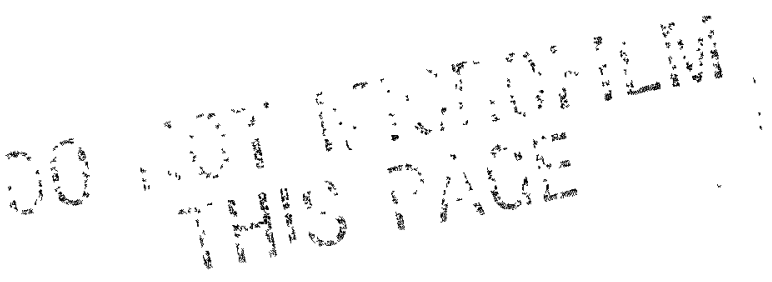

\section{DISCLAIMER}

This report was prepared as an account of work sponsored by an agency of the United States Government. Neither the United States Government nor any agency thereof, nor any of their employees, makes any warranty, express or implied, or assumes any legal liability or responsibility for the accuracy, completeness, or usefulness of any information, apparatus, product, or process disclosed, or represents that its use would not infringe privately owned rights. Reference herein to any specific commercial product, process, or service by trade name, trademark, manufacturer, or otherwise, does not necessarily constitute or imply its endorsement, recommendation, or favoring by the United States Government or any agency thereof. The views and opinions of authors expressed herein do not necessarily state or reflect those of the United States Government or any agency thereof. 
LA-10906

UC-4 and UC-10

Issued: May 1987

LA- -10906

DE87 010648

\title{
Improved Recovery and Purification of Plutonium at Los Alamos Using Macroporous Anion Exchange Resin
}

\author{
S. Fredric Marsh
}

DISCLAIMER

\begin{abstract}
This report was prepared as an account of work sponsored by an agency of the United States
Government. Neither the United States Governments employees, makes any warranty, express or implient nor any agency thereof, nor any of thei bility for the accuracy, completeness, or usefulness of assumes any legal liability or responsiprocess disclosed, or represents that its use would not infringermation, apparatus, product, or manufacin to any specific commercial product, process, or serivately owned rights. Refermanufacturer, or otherwise does not necessarily constitute service by trade name, trademark, mendation, or favoring by the United States Gonstitute or imply its endorsement, recomand opinions of authors expressed herein Government or any agency thereof. The views United States Government or any agency thereof necessarily state or reflect those of the
\end{abstract}

\section{MASTER}

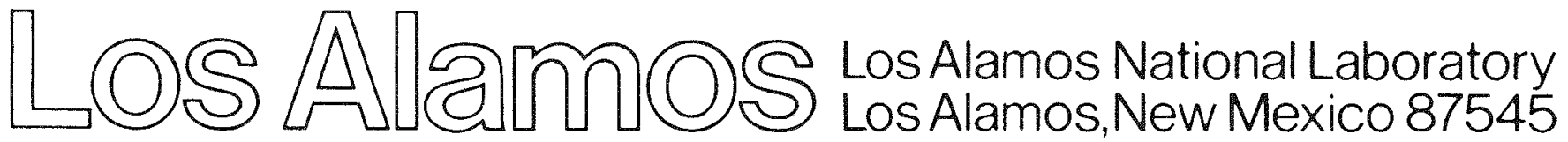




\title{
IMPROVED RECOVERY AND PURIFICATION OF PLUTONIUM AT LOS ALAMOS USING MACROPOROUS ANION EXCHANGE RESIN
}

by

\author{
S. Fredric Marsh
}

\begin{abstract}
For almost 30 years, Los Alamos National Laboratory has used anion exchange in nitric acid as the major aqueous process for the recovery and purification of plutonium. One of the few disadvantages of this system is the particularly slow rate at which the anionic nitrato complex of $\mathrm{Pu}(\mathrm{IV})$ equilibrates with the resin. The Nuclear Materials Process Technology Group at Los Alamos recently completed an ion exchange development program that focused on improving the slow sorption kinetics that limits this process. A comprehensive investigation of modern anion exchange resins identified porosity and bead size as the properties that most influence plutonium sorption kinetics. Our study found that small beads of macroporous resin produced a dramatic increase in plutonium process efficiency. The Rocky Flats Plant has already adopted this improved ion exchange technology, and it currently is being evaluated for use in other DOE plutonium-processing facilities.
\end{abstract}

\section{INTRODUCTION}

Nearly three decades have passed since Ryan and Wheelwright completed their extensive study ${ }^{1}$ of the anion exchange behavior of plutonium in nitric acid. Shortly thereafter, Faris ${ }^{2}$ measured the distribution coefficients of 60 elements on anion exchange resin from nitric acid. The data of Faris (Fig. 1) confirm that anion exchange in nitric acid is a nearly ideal system for plutonium, as no metal ion is more strongly sorbed than $\mathrm{Pu}(\mathrm{IV})$, and few other ions show even moderate sorption from nitric acid. The nuclear industry quickly adopted this anion exchange system, and it is now the major aqueous process used to recover and purify plutonium.
One of the few disadvantages of this system is the particularly slow rate at which the hexanitrato complex of $\mathrm{Pu}(\mathrm{IV})$ equilibrates with the resin. Sorption is so slow, in fact, that Ryan and Wheelwright estimated that final equilibrium would require several months. A more recent study by Streat $^{3}$ reported that 547 hours was required for complete sorption of plutonium onto a single resin bead.

Boyd, Adamson, and Myers ${ }^{4}$ identified three ratecontrolling mechanisms for such anion exchange systems. These are (1) film gradient diffusion at the resin bead surface, (2) diffusion within the resin matrix, and (3) chemical reaction at the exchange site. Ryan and Wheelwright ${ }^{1}$ found that plutonium sorption was limited by the second rate-controlling mechanism, diffusion within the bead. Early attempts to overcome slow 


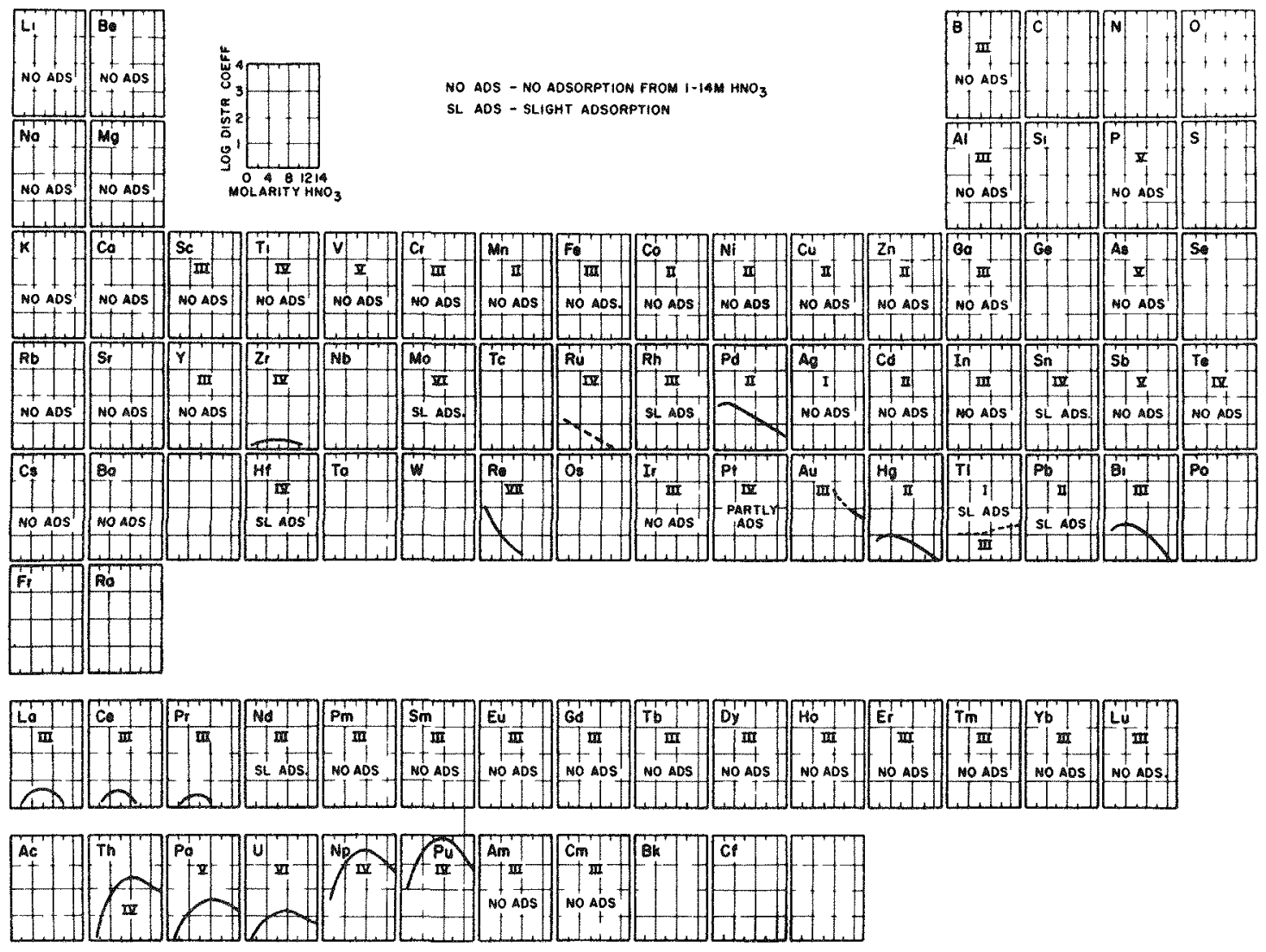

Fig. 1. Distribution of elements from nitric acid onto strong-base anion exchange resin.

diffusion within the beads led to the use of low crosslinked resin whose larger pores presented fewer physical obstructions to the large $\left[\mathrm{Pu}\left(\mathrm{NO}_{3}\right)_{6}\right]=$ ions. Small resin beads also have been used to improve sorption kinetics because diffusion within the bead is inversely proportional to the square of the bead radius. ${ }^{5}$

Early investigators agreed that the need for anion exchange resin of high porosity could best be met at that time by using a gel-type resin of low cross-linkage, such as Dowex 1x4. Consequently, the gel-type resin of low cross-linkage specified in these early studies was quickly adopted for use in the standard processing procedures used by the nuclear industry. Although this resin has worked reasonably well for more than a quarter of a century, slow sorption kinetics remained the major limitation of the process.

The purpose of our investigation was to identify, by evaluating a wide variety of commercially available anion exchange resins, the resin best suited for processing plutonium in nitric acid. Major variables included resin structure, resin porosity, resin bead size, nitric acid concentration, and dynamic contact time.

\section{REAGENTS}

\section{Nitric Acid}

The reagent-grade nitric acid used throughout this study was diluted as needed using single distilled water.

\section{Anion Exchange Resin}

Gel-type Dowex $1 \times 4$ and macroporous Dow MSA-1 resins were obtained from the Dow Chemical Company, Midland, Michigan.

Macroporous IRA-900 and IRA-938 resins were obtained from Rohm \& Haas, Philadelphia, Pennsylvania.

Macroporous Lewatit MP-500-FK (40- to 70-mesh) resin, manufactured by Bayer AG in the Federal Republic of Germany, was obtained from Mobay Chemical Company, Pittsburgh, Pennsylvania. 


\section{EXPERIMENTAL}

\section{Assay Technique}

We used a wrist-action shaker, shown in Fig. 2, to achieve dynamic batch contacts. Liquid scintillation vials, also shown in Fig. 2, contained a measured weight of dry, nitrate-form resin and a measured volume of solution. Each solution initially contained ${ }^{239} \mathrm{Pu},{ }^{237} \mathrm{U}$, and ${ }^{241} \mathrm{Am}$ in a selected concentration of nitric acid. After completion of the first dynamic contact period, we removed a measured portion of the aqueous phase for assay. The dynamic contacts were quickly resumed and continued until completion of the second contact period, when we removed another aqueous portion for assay. This procedure was repeated until all scheduled contact periods were completed.
Aqueous portions were in all cases assayed by gamma spectrometry, which allowed us to measure and compare each portion of resin-contacted solution with an identical volume of uncontacted solution. The difference between these two measurements represents the quantity of the selected radioisotope sorbed on the resin. Gamma spectrometric assay was based on the $59.5-\mathrm{keV}, 129-\mathrm{keV}$, and $208-\mathrm{keV}$ gamma-ray peaks of ${ }^{241} \mathrm{Am},{ }^{239} \mathrm{Pu}$, and ${ }^{237} \mathrm{U}$, respectively, as shown in Fig. 3. The oxidation states of these three actinides immediately before the resin contact were Am(III), $\mathrm{Pu}(\mathrm{IV})$, and $\mathrm{U}(\mathrm{VI})$. Any change in oxidation state during the contact periods is unlikely.

Dynamic contact periods ranged from 3 minutes to 3 hours. Because the sorption kinetics of plutonium in this system is particularly slow, ${ }^{3}$ we have no reason to believe that the distribution coefficient (Kd) values measured after 3 -hour contacts even approximate

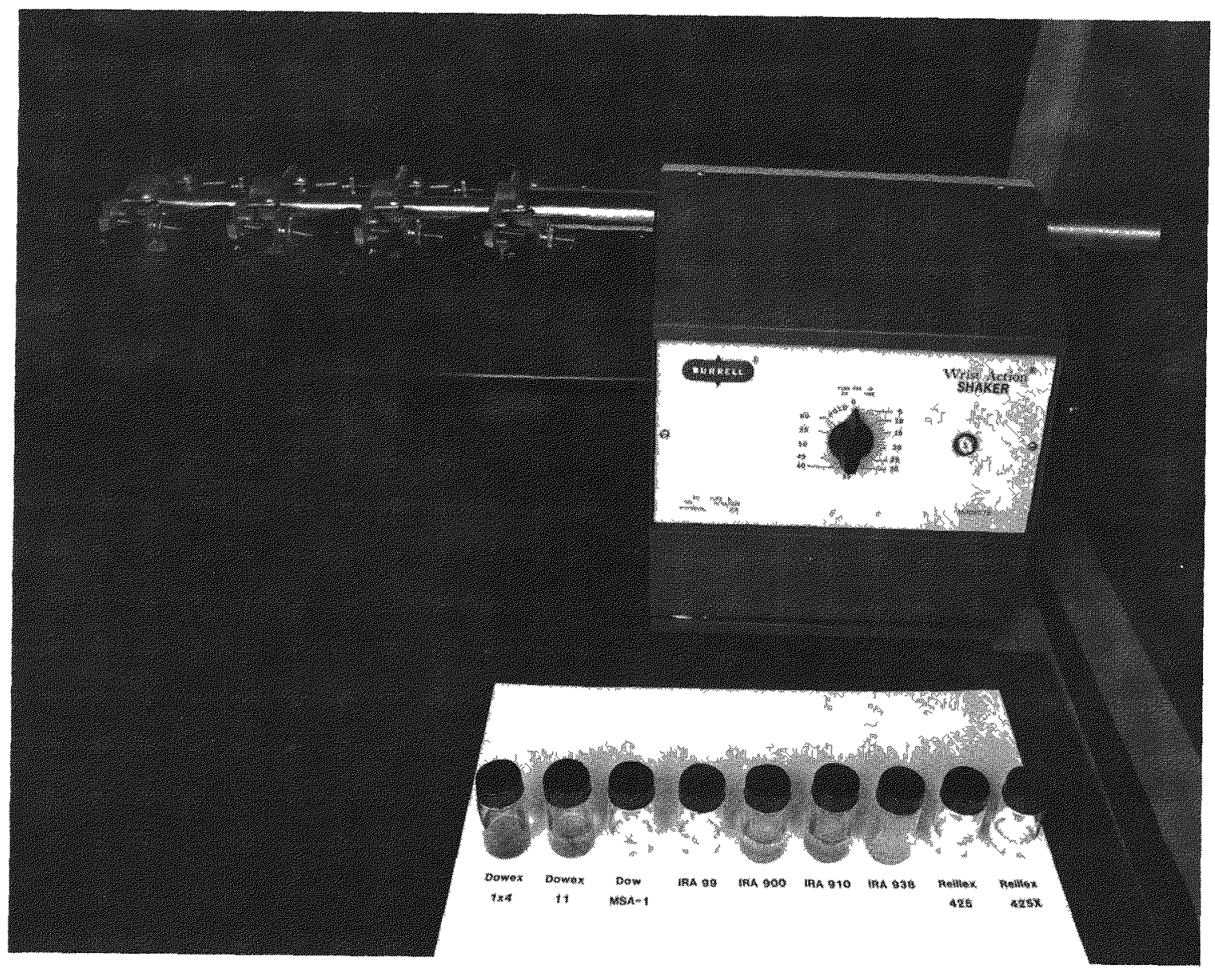

Fig. 2. Apparatus used for small-scale dynamic contact studies of anıon exchange resins 


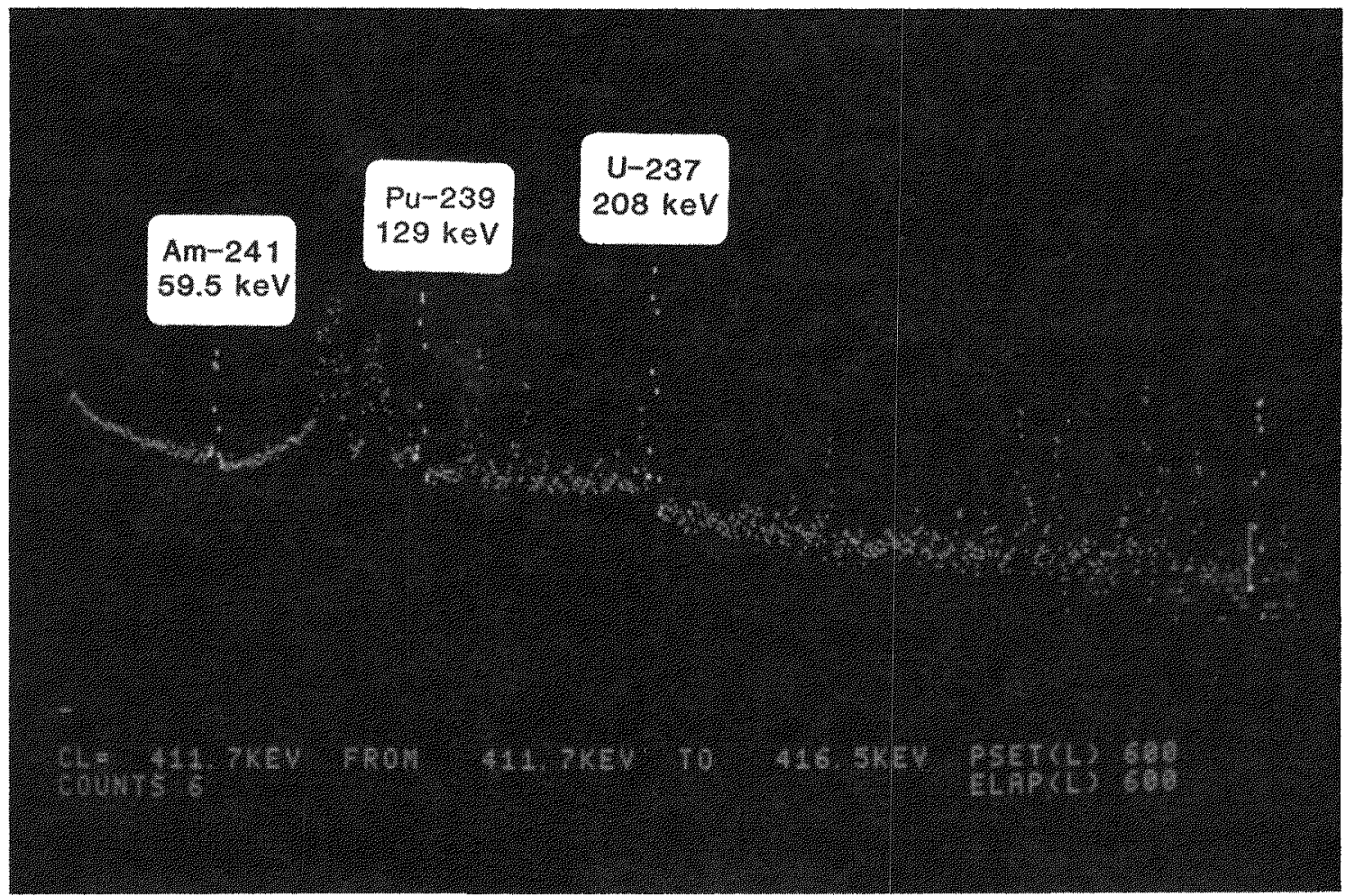

Fig. 3. Gamma spectrum showing the specific energies used to assay americium, plutonium, and uranium.

Kd values at equilibrium. These measurements do, however, allow us to compare all resins on an identical basis during short time periods that simulate the brief residence time of an aqueous solution as it flows through a stationary bed of anion exchange resin.

\section{Computation of $\mathrm{Kd}$ Values}

We computed distribution coefficients for each contact period as follows:

$\mathrm{Kd}=\frac{\text { concentration of element per milliliter of wet resin }}{\text { concentration of element per milliliter of solution }}$. tion:

In practice, Kd values were calculated by the equa-

$$
\mathrm{Kd}=\left(\frac{\mathrm{A}_{\mathrm{t}}-\mathrm{A}_{1}}{\mathrm{~A}_{1}}\right)\left(\frac{\mathrm{V}_{1}}{\mathrm{~V}_{\mathrm{r}}} \text { or } \frac{\mathrm{V}_{\mathrm{l}}}{\mathrm{W}_{\mathrm{r}}}\right)
$$

where

$A_{t}$ is the activity of the actinide initially in the liquid, $A_{1}$ is the actinide activity in the liquid after contact, $\mathrm{V}_{\mathrm{I}}$ is the liquid volume, $V_{r}$ is the volume of wet resin, and $W_{r}$ is the weight of dry resin.

Because each resin/acid combination was used for a series of sequential contact measurements, the liquidto-resin ratio changed as each aqueous portion was removed for assay. We corrected for this changing ratio, as well as for the decrease in the total activity remaining in a vial after the removal of each aqueous portion. 
We have elected to express $\mathrm{Kd}$ in terms of wet-resin volume, contrary to the common practice of expressing $\mathrm{Kd}$ in terms of dry-resin weight. Because water accounts for as much as two-thirds of the weight of as-received resin, the procedures used to obtain "dry" resin must be reproducible and clearly defined. Many published studies specify "air-drying" to obtain "dry" resin. (Air-drying in Los Alamos, at 7400 feet with $20 \%$ relative humidity, is likely to yield resin with a substantially different water content from that of resin air-dried at sea level with $90 \%$ relative humidity.) Some investigators dry their resin at elevated temperatures, others use vacuum, and still others use some combination of elevated temperature and vacuum. This assortment of drying procedures can make it difficult, if not impossible, to reproduce published data.

On the other hand, the volume of wet resin in water can be measured easily and reproducibly in any laboratory by using equipment no more elegant than a graduated cylinder. Furthermore, when resin is selected for a given process, the relative performance must be predicted for a column of specified dimensions and volume. Wet-resin volume therefore seems inherently more useful than dry-resin weight for comparing the performance of resins.

For these reasons, we have chosen to present our measured $\mathrm{Kd}$ values in terms of the volume of nitrateform resin in water. However, for those who wish to convert our $\mathrm{Kd}$ values to a dry-resin weight, we obtained the "Los Alamos air-dried" weights per volume of wet resin, and present them in Table I.

TABLE I. Relationship Between Wet-Resin Volume and Dry-Resin Weight

\begin{tabular}{lcc}
\hline Resin & $\begin{array}{c}\text { Air-dried weight } \\
(\text { dry g/wet ml })^{a}\end{array}$ & $\begin{array}{c}\text { Conversion } \\
\text { factor }^{b}\end{array}$ \\
\hline Dowex 1x4 & 0.331 & 3.02 \\
Dow MSA-1 & 0.363 & 2.75 \\
IRA-900 & 0.342 & 2.92 \\
IRA-938 & 0.196 & 5.10 \\
Lewatit & 3.29 \\
MP-500-FK & 0.305 & \\
\hline a Volume of nitrate-form resin in water. \\
bDistribution coefficients reported herein may be mul- \\
tiplied by these factors to obtain Kd values per gram \\
of "air-dried" resin. \\
\hline
\end{tabular}

\section{Resins Studied}

Because anion exchange in nitric acid continues to be the major process used to recover and purify plutonium at the Los Alamos Plutonium Facility (TA-55), our initial efforts to improve this process focused on overcoming the slow sorption kinetics. Our experimental studies emphasized macroporous resins, in which the styrene/divinylbenzene structure is polymerized in the presence of an inert substance that produces extra-large pores in the resulting polymer. The contrast between conventional gel-type resin and macroporous resin is shown in Figs. 4 and 5. These are scanning electron micrographs of the gel-type resin formerly used and the macroporous resin currently used, respectively. Note that the surface of the gel-type resin appears solid, even at $10,000 \times$ magnification, whereas macroporous resin clearly exhibits pore structure at this same magnification.

In our small-scale studies, we evaluated many varieties of anion exchange resin of both gel and macroporous structure (Table II). The resins listed in Table II include an unusually large number of poly-4vinylpyridine resins, which gave occasionally rapid, but highly variable sorption kinetics for plutonium. The highly variable nature of the sorption data for these resins was finally traced to a linear polymer impurity that remained from the resin manufacturing process. Rather than fill many pages with descriptions of resins that performed poorly, we describe here only those resins whose performance qualifies them as candidates for plutonium processing, and compare them to resins traditionally used in this process. Other major variables studied in our investigation were acid concentration and dynamic contact time.

Dowex 1x4. Gel-type Dowex 1x4 resin had been used routinely for recovering and purifying plutonium at the Los Alamos Plutonium Facility for 25 years before 1984, when the performance of resin identified and purchased as Dowex $1 \times 4$ from an intermediate resin processor deteriorated to an unacceptable level. Consequently, the unacceptable resin was replaced with macroporous Dow MSA-1 resin because small-scale column experiments had demonstrated its superior performance. 


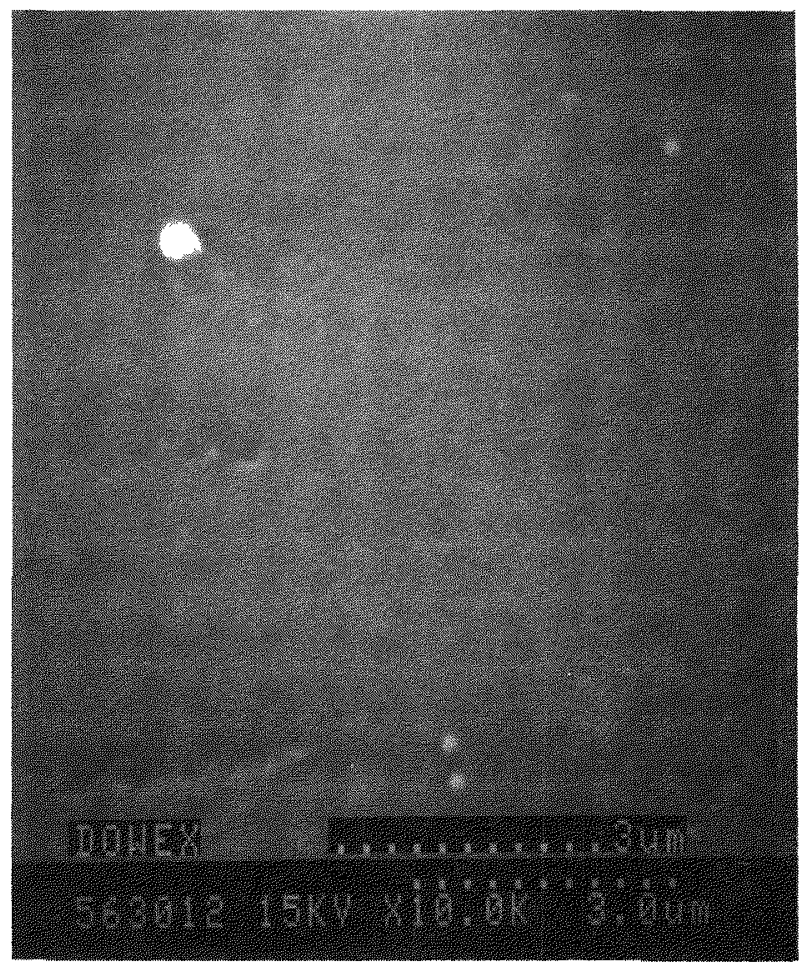

Fig. 4. Scanning electron micrograph of gel-type Dowex $1 \times 4$ resin $(10,000 \times$ magnification $)$.

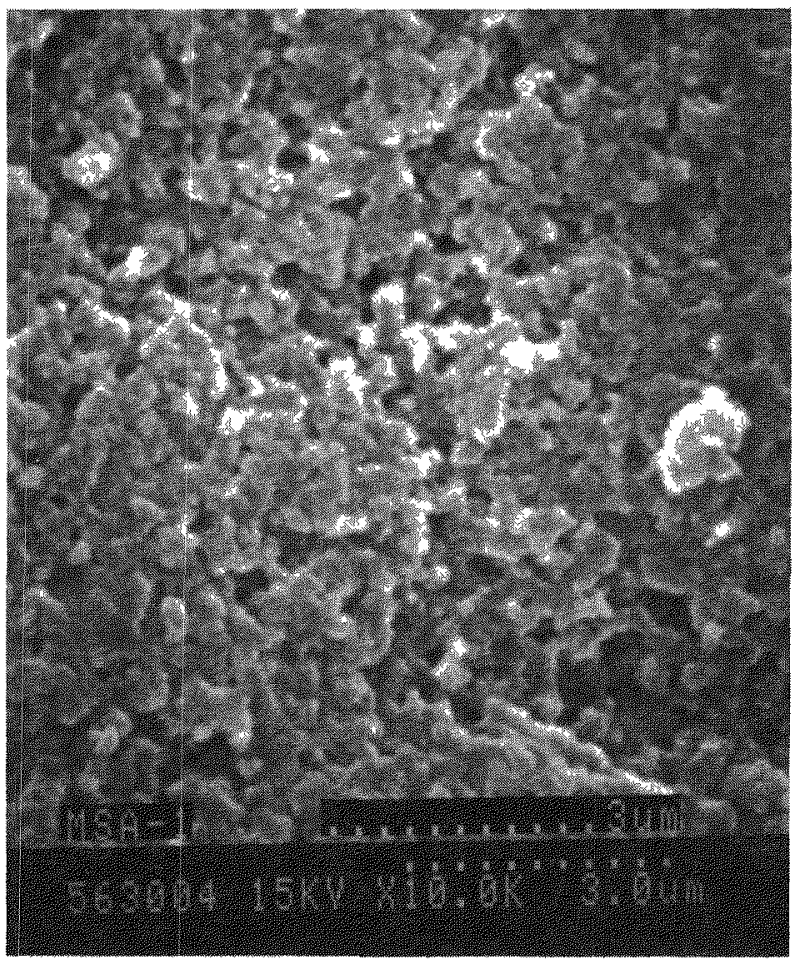

Fig. 5. Scanning electron micrograph of macroporous Dow MSA-1 resin $(10,000 \times$ magnification).

TABLE II. Anion Exchange Resins Tested at Los Alamos

\begin{tabular}{lll}
\hline Manufacturer & Resin & Comments \\
\hline Dow Chemical Co. & Dowex 1x4 & strong base, gel-type \\
& Dowex 11 & strong base, gel-type \\
& Dow MSA-1 & strong base, macroporous \\
& Dow A-1 & weak acid, iminodiacetate, chelating \\
Rohm \& Haas & IRA-99 & weak base, macroporous \\
& IRA-900 & strong base, macroporous \\
& IRA-904 & strong base, macroporous \\
& IRA-910 & strong base, macroporous \\
& IRA-938 & strong base, macroporous \\
& IRA-958 & strong base, macroporous \\
Diamond Shamrock & Duolite ES-63 & intermediate acid, phosphonate, chelating \\
& Duolite ES-467 & weak acid, aminophosphonate, chelating \\
Sybron Chemical & Ionac A-580 & strong base, pyridinium polymer \\
Reilly Chemical & P-4-VP & strong base, poly-4-vinylpyridine, more than \\
Bayer AG (Germany) & Lewatit MP-500-FK & 20 combinations of porosity and cross-linkage \\
\hline \hline
\end{tabular}


Whether the observed unacceptable performance of Dowex 1x4 resulted from manufacturing problems or from alteration or mislabeling by the intermediate supplier has not been established. To minimize the possibility of mislabeling or alteration of resin after its manufacture, we obtained the resins used in this study directly from the producer whenever possible.

To further minimize the possibility of generating misleading data from questionable Dowex $1 \times 4$ resin, we used for this study a several-year-old portion of Dowex $1 \times 4$ that represented the acceptable performance typical of many years of operation at Los Alamos.

Dow MSA-1. Dow MSA-1, like Dowex 1x4, is a strong-base anion exchange resin that incorporates tetraalkylammonium exchange groups on styrene/ divinylbenzene copolymer beads. The highly significant difference between these two resins is that Dow MSA-1 resin is polymerized in a manner that produces the macroporous structure shown in Fig. 5.

Amberlite IRA-900. Amberlite IRA-900 was of particular interest, as its manufacturer, Rohm \& Haas, defines it to be the equivalent of Dow MSA-1.

Amberlite IRA-938. Because Amberlite IRA938 has by far the largest pore structure of any resin studied, the diffusion-controlled rate of exchange was expected to be rapid. This, in fact, was the case. Unfortunately, the highly porous structure of IRA-938 contributes directly to its low mechanical strength. A scanning electron micrograph (SEM) of IRA-938 resin (Fig. 6) shows that the interlocking solid structure of other resins (Figs. 4 and 5) is lacking. Instead, IRA938 appears to be an agglomeration of microspheres that are approximately $10 \mu \mathrm{m}$ in diameter. (Note also that the SEM shown in Fig. 6 was taken at tenfold lower magnification than the SEMs shown in Figs. 4 and 5.)

IRA-938 resin is so fragile that it literally disintegrated during the relatively gentle agitation of the wrist-action shaker used in our dynamic contacts. The ultrafine resin particles that remained suspended in the aqueous phase made reliable assay of the aqueous phase impossible. Because the continuous disintegration of such fragile resin in a plant process would cause excessive loss of plutonium to waste streams and plugging of process valves and filters, we consider IRA-938 resin unsuitable for plant process use at Los Alamos.

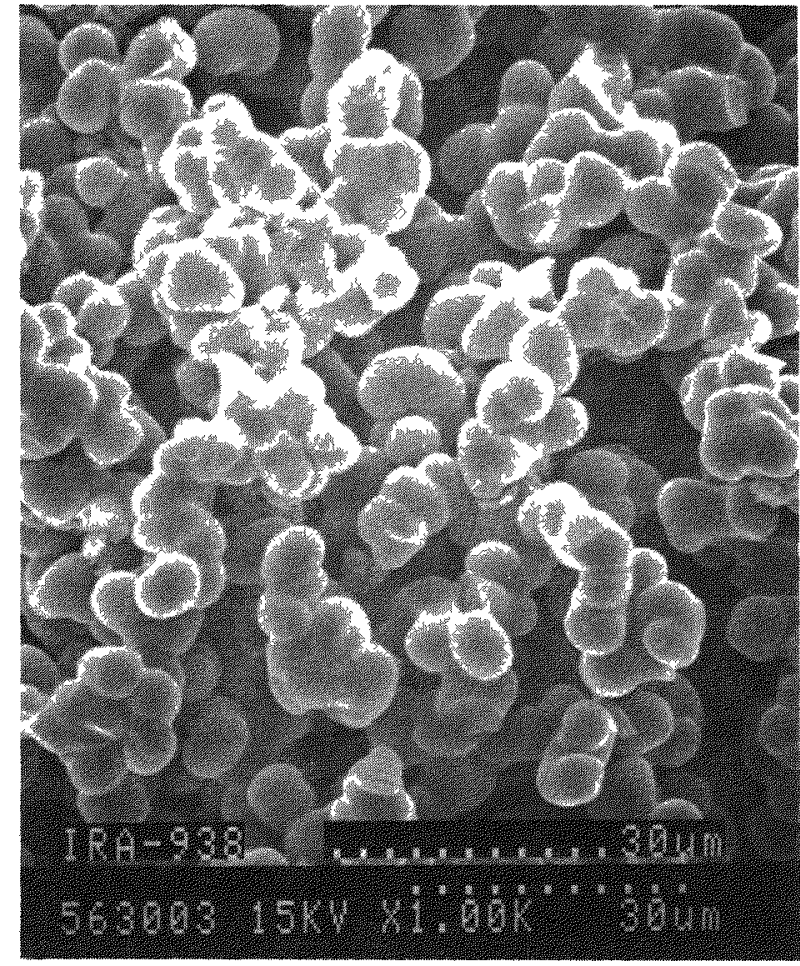

Fig. 6. Scanning electron micrograph of Amberlite IRA938 resin $(10,000 \times$ magnification $)$

Lewatit MP-500-FK. Lewatit MP-500 is a macroporous, strong-base anion exchange resin, manufactured by Bayer AG in the Federal Republic of Germany, that is similar in structure to Dow MSA-1 and Amberlite IRA-900. This resin is attractive because it is available as 40 - to 70 -mesh spherical resin beads, designated Lewatit MP-500-FK. All domestic sources of macroporous strong-base anion exchange beads, by contrast, supply only a coarse 20 - to 50 -mesh range.

\section{RESULTS AND DISCUSSION}

The large amount of data generated in this study can be presented in many ways. Because plutonium sorption kinetics has been the major limitation of the nitrate anion exchange process, we have chosen to present our data in a manner that emphasizes differences in sorption kinetics. 
General. As expected, americium showed no significant sorption on any of the resins studied from any concentration of nitric acid and therefore was not included in the graphical presentation of measured $\mathrm{Kd}$ values. In all cases, uranium equilibrated rapidly with the resin, whereas plutonium sorption was consistently much slower. Finally, a comparison of plutonium $\mathrm{Kd}$ values for the shortest contact time and the longest contact time confirms that plutonium equilibrates more rapidly from dilute nitric acid, in agreement with calculated predictions of James. ${ }^{6}$

Effect of Resin Bead Size. The effect of resin bead size on plutonium sorption kinetics (Fig. 7) is demonstrated by comparing two different-size fractions of the same Dowex $1 \times 4$ resin. The observed faster kinetics of smaller beads is in complete agreement with theory and was fully expected. However, the benefits associated with using smaller resin beads reach a point of diminishing returns when the increasing resistance to liquid flow eventually results in unacceptably high liquid back-pressure.

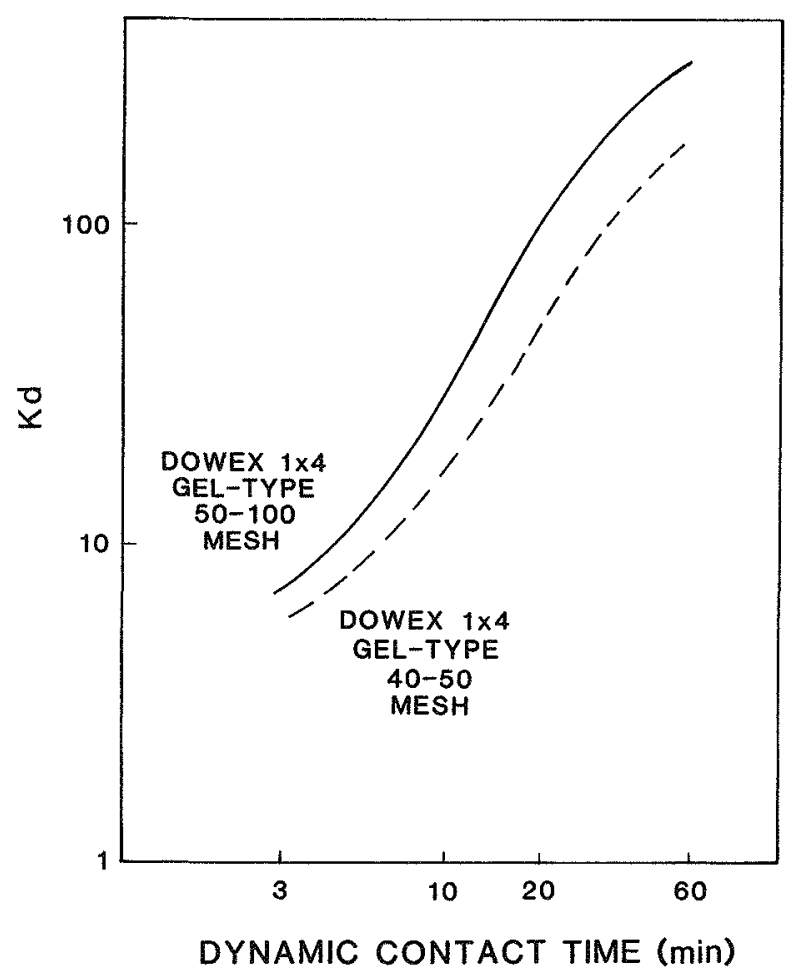

Fig. 7. Sorption of $\mathrm{Pu}(\mathrm{IV})$ from $7 M$ nitric acid as a function of resin bead size.
Effect of Resin Porosity. The effect of resin porosity on plutonium sorption kinetics (Fig. 8) is demonstrated by comparing similar-size fractions of two resins of different porosity. Dowex $1 \times 4$ is a gel-type resin, whereas Dow MSA-1 is a macroporous resin. The relative porosities of these two resins are shown in Figs. 4 and 5, respectively.

From the results of many small-scale experiments, we concluded that an ideal resin for processing plutonium would incorporate both small bead size and high porosity. Because small, spherical beads of macroporous resin were not available from any domestic manufacturer, we developed an in-house hydraulic system capable of separating cubic-foot quantities of 40 to 50 -mesh beads from as-received 20- to 50-mesh macroporous resin. Use of a separated, smaller-size fraction of macroporous resin in our full-scale plant process resulted in a dramatic improvement in performance; the apparent capacity of the resin for plutonium tripled, while the plutonium content of the effluent waste stream decreased by a factor of 10 .

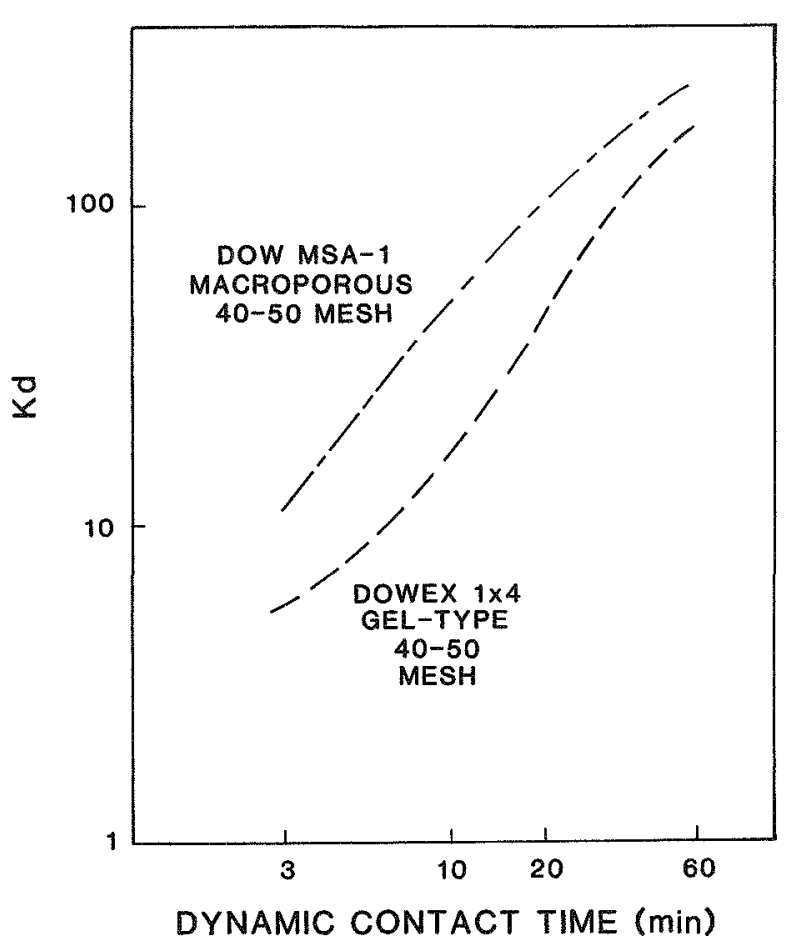

Fig. 8. Sorption of $\mathrm{Pu}(\mathrm{IV})$ from $7 M$ nitric acid as a function of resin porosity. 
Lewatit MP-500-FK Resin. Meanwhile, we attempted to find a foreign supplier of small, spherical beads of macroporous resin. We finally contacted Mobay Chemical Corporation, a U. S. company that represents Bayer AG in the Federal Republic of Germany. Testing of Bayer's Lewatit MP-500-FK resin in small-scale experiments and full-scale processes confirmed our expectation of significantly faster kinetics when these smaller beads are used. In Fig. 9, which shows plutonium distribution onto all three resins as a function of contact time, the highest curve reflects the superior kinetics of the Lewatit resin.

The dramatic effect of dynamic contact time also is demonstrated in Figs. 10 and 11. Figure 10 compares the distribution coefficients of Dowex $1 \times 4$ and Lewatit MP-500-FK as a function of nitric acid concentration, after a dynamic contact period of 3 hours. The curves for this relatively long contact period are virtually identical.

Figure 11, however, compares these same two resins after a dynamic contact period of only 15 minutes. The superiority of the Lewatit resin is clearly apparent for this shorter contact period that simulates the actual residence time of feed solution flowing through a fullscale anion exchange column. These two resins are

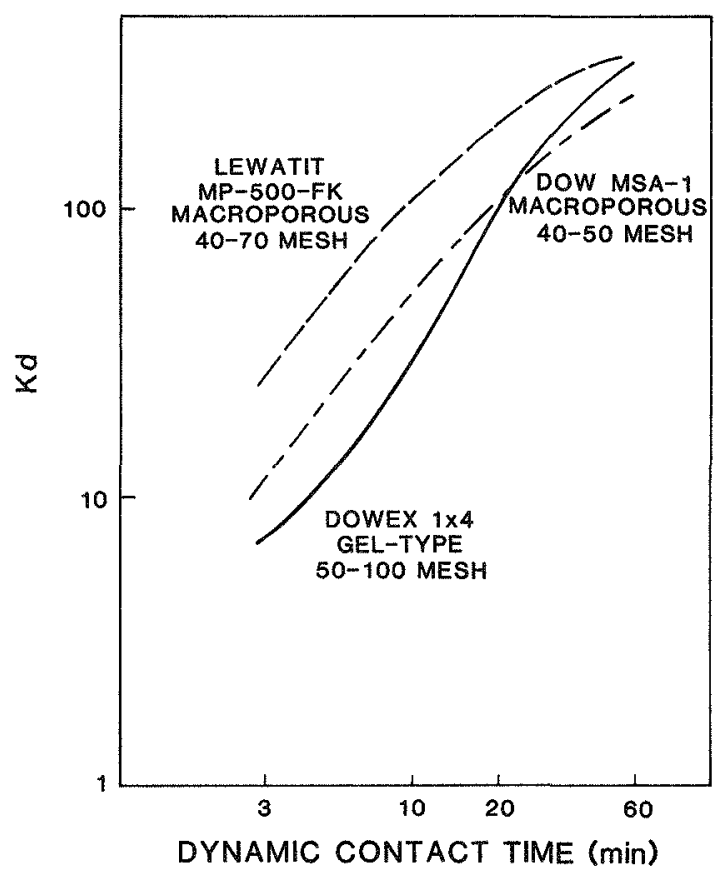

Fig. 9. Sorption of $\mathrm{Pu}(\mathrm{IV})$ from $7 M$ nitric acid on gel-type Dowex 1x4, macroporous Dow MSA-1, and macroporous Lewatit MP-500-FK resins.

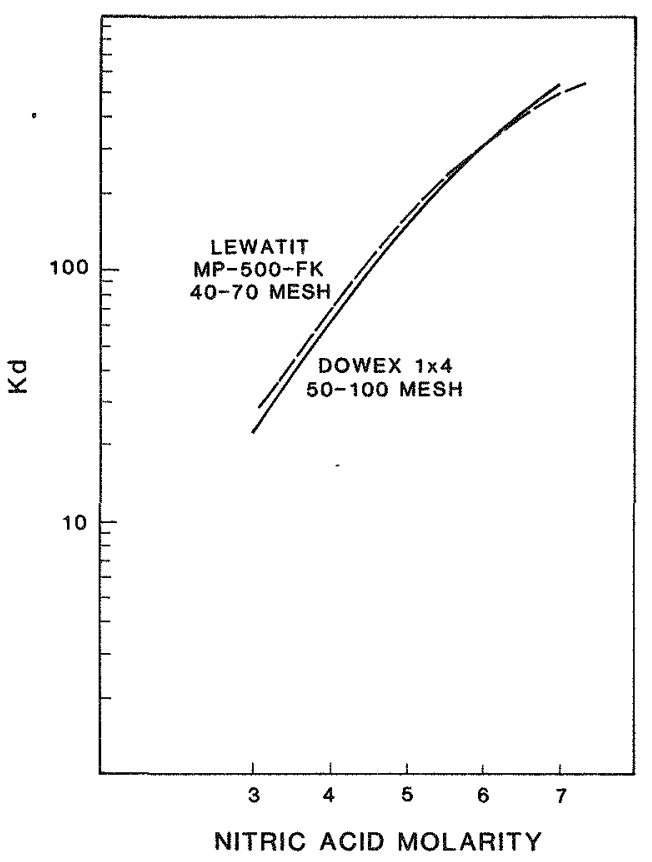

Fig. 10. Sorption of $\mathrm{Pu}(\mathrm{IV})$ on Dowex $1 \times 4$ and Lewatit MP-500-FK resins, as a function of nitric acid concentration, for a 3-hour dynamic contact period.

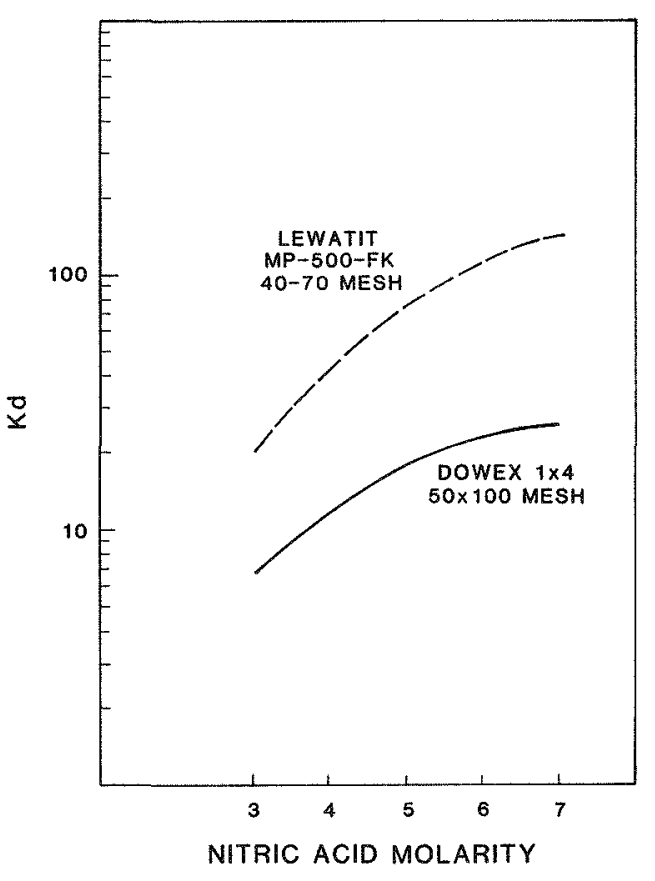

Fig. 11. Sorption of $\mathrm{Pu}(\mathrm{IV})$ on Dowex $1 \times 4$ and Lewatit MP-500-FK resins, as a function of nitric acid concentration, for a 15-minute dynamic contact period. 
compared as a function of dynamic contact time for only $7 \mathrm{M}$ nitric acid in Fig. 12 . The fallacy in the common practice of using published "equilibrium" distribution coefficient values to predict plutonium behavior is readily apparent.

Uranium/Plutonium Separation. Uranium equilibrated much more rapidly than plutonium with all resins studied. The combination of rapid sorption and consistently low uranium distribution coefficients results in the similar curves for Dowex $1 \times 4$ and Lewatit MP-500-FK shown in Fig. 13.

Because the Lewatit resin greatly affects the sorption kinetics of plutonium, whereas it affects the sorption kinetics of uranium only slightly, macroporous Lewatit resin also provides significantly increased separation factors between uranium and plutonium, as shown in Fig. 14.

Summary. Lewatit MP-500-FK resin offers advantages for plutonium processing in every category that we can measure. When compared with the other resins tested, Lewatit resin costs less, offers greater capacity for plutonium, loads faster, elutes faster (all of which result in greatly increased throughput), and yields a plutonium product of higher purity. Furthermore, loss of plutonium to the effluent waste stream is significantly lower.

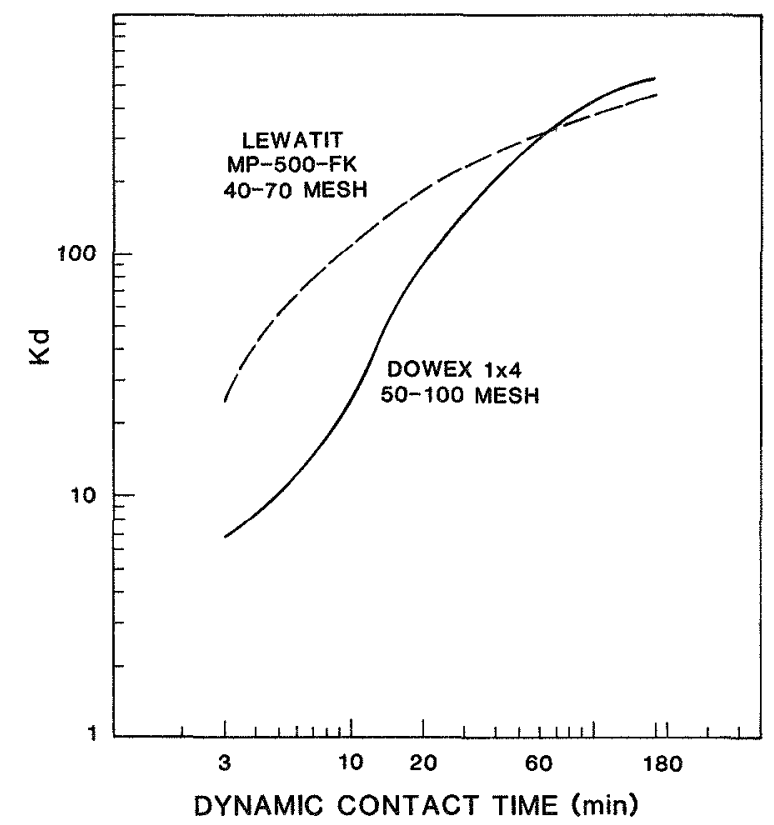

Fig. 12. Sorption of $\mathrm{Pu}(\mathrm{IV})$ from $7 M$ nitric acid on Dowex $1 \times 4$ and Lewatit MP-500-FK resins, as a function of dynamic contact time.

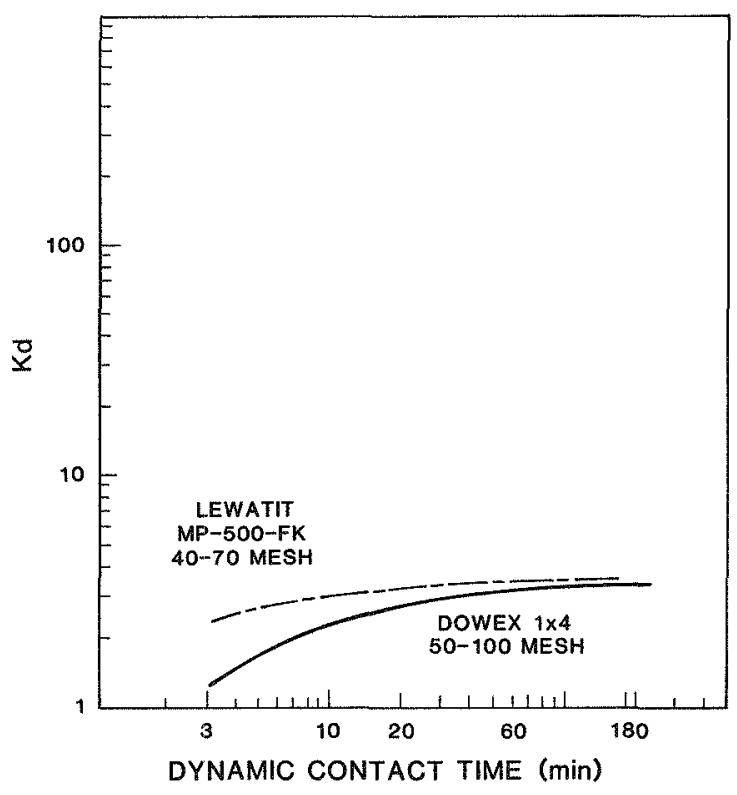

Fig. 13. Sorption of U(VI) from $7 M$ nitric acid on Dowex $1 \times 4$ and Lewatit MP-500-FK resins, as a function of dynamic contact time.

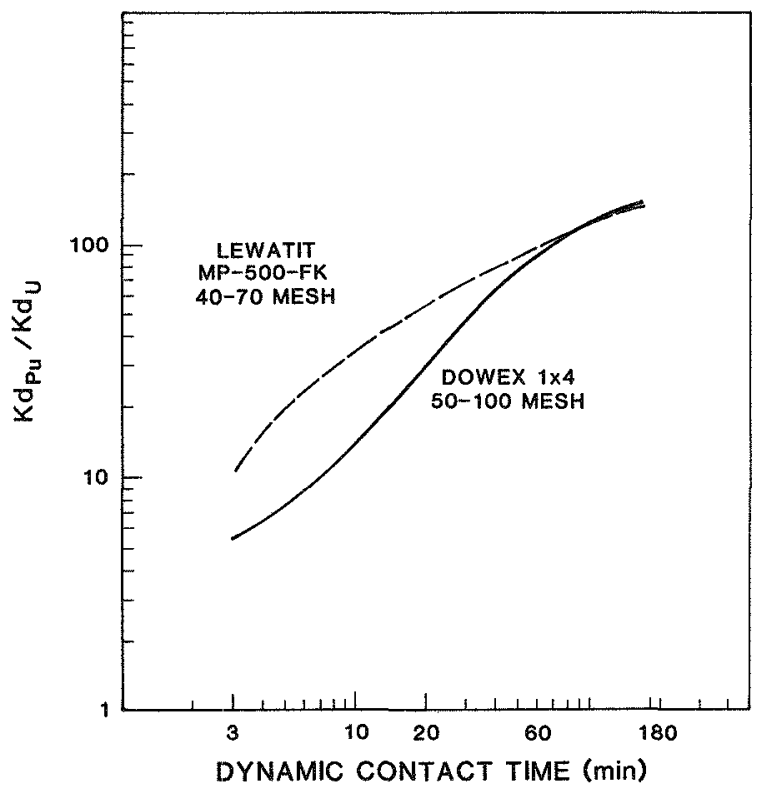

Fig. 14. $\mathrm{Pu}(\mathrm{IV}) / \mathrm{U}(\mathrm{VI})$ separation factors from $7 M$ nitric acid on Dowex $1 \times 4$ and Lewatit MP-500-FK resins, as a function of time. 


\section{TECHNOLOGY TRANSFER}

Soon after we shared this improved anion exchange technology ${ }^{7}$ with Rocky Flats Plant personnel, they performed an independent comparison ${ }^{8}$ of macroporous resins with the IRA-938 resin formerly used at Rocky Flats. Their results confirmed the Los Alamos conclusion that Lewatit MP-500-FK resin far outperforms all others tested. Of particular interest is the Rocky Flats finding that Lewatit MP-500-FK resin, when compared with IRA-938 resin, provides essentially twice the capacity for plutonium, while it also allows the sorbed plutonium to be eluted in half the volume. As this report is being written, Savannah River and Hanford personnel also are evaluating Lewatit MP-500-FK for use at those facilities.

\section{CONCLUSIONS}

1. High-porosity, macroporous anion exchange resin sorbs the anionic nitrato complex of plutonium more rapidly than does gel-type resin. Macroporous resin therefore is preferred for processing plutonium.

2. Small resin beads of strong-base anion exchange resin sorb the anionic nitrato complex of plutonium more rapidly than do large resin beads. Small resin bead size is therefore preferred for processing plutonium.

3. Either small, spherical beads of gel-type resin or large beads of macroporous resin may be purchased from domestic manufacturers, but none offers the combination of macroporous resin in small bead size. Lewatit MP-500-FK resin, manufactured by Bayer AG in the Federal Republic of Germany, combines high porosity and small bead size. This 40 - to 70-mesh, macroporous resin is primarily responsible for the dramatic improvement in performance and efficiency that we have attained in our plutonium anion exchange process at Los Alamos.

4. Amberlite IRA-938, which offers by far the largest pore size of the resins studied, equilibrates rapidly with the plutonium complex. However, the highly porous structure contributes directly to the poor mechanical strength that causes IRA-938 resin to fracture under relatively gentle agitation. The severe problems that can result from resin disintegrating into a fine suspension of microparticles make this resin unsuitable for process use. (The relative merits of IRA-938 resin have become academic, as Rohm $\&$ Haas has recently discontinued production of this resin.)

5. Uranium equilibrates rapidly with all resins studied from all concentrations of nitric acid; however, $\mathrm{Kd}$ values of uranium are consistently much lower than those of plutonium.

6. Because macroporous resin offers more rapid sorption of plutonium, but not of uranium, when compared with gel-type resin, there is an increased separation factor between these two actinides. In-plant process use of Lewatit MP-500-FK resin at the Los Alamos Plutonium Facility has demonstrated not only a dramatic increase in process efficiency and throughput, but also a significant improvement in product purity.

7. The in-plant performance of most anion exchange resins is best when the resin is new and gradually deteriorates thereafter as the resin is degraded by chemical and radiolytic processes. An unexpected bonus of Lewatit MP-500-FK resin is that its performance actually improved during the first eight months of routine in-plant process use. The capacity of this resin for plutonium noticeably increased, while the volume of eluting solution required to recover the sorbed plutonium simultaneously decreased by $25 \%$. The explanation for this improved performance, although not currently understood, is being investigated.

\section{ACKNOWLEDGMENTS}

The Los Alamos Plutonium Facility at TA-55 is unique in that it combines plutonium research and production within the same organization. Such a combination allows us to rapidly test and evaluate process improvement ideas and to quickly incorporate the best of these into our routine operations. A major share of the credit for the recent dramatic improvement in plutonium processing efficiency therefore belongs to key members of the production team who are responsible for converting promising research ideas into the reality of major production improvements. I gratefully acknowledge the essential contributions of Tim Gallegos, Jeff Hatchell, Bill McKerley, Arch Nixon, and Willard Williams. 


\section{REFERENCES}

1. J. L. Ryan and E. J. Wheelwright, "The Recovery, Purification, and Concentration of Plutonium by Anion Exchange in Nitric Acid," U. S. Atomic Energy Commission report HW-55893(del) (1959).

2. J. P. Faris and R. F. Buchanan, "Applications of Anion-Exchange Spectrographic Procedures in Nitric Acid Medium," U. S. Atomic Energy Commission report TID-7606, pp. 185-194 (1960).

3. M. Streat, "Kinetics of Slow Diffusing Species in Ion Exchangers," Reactive Polymers 2, 79-91 (1984).

4. G. E. Boyd, A. W. Adamson, and L. S. Myers, "The Exchange Absorption of Ions from Aqueous Solutions by Organic Zeolites II, Kinetics," $J$. Am. Chem. Soc. 69, 2836-2848 (1947).
5. D. Reichenberg, "Properties of Ion Exchange Resins in Relation to Their Structure III, Kinetics of Exchange," J. Am. Chem. Soc. 75, 589-597 (1953).

6. D. B. James, "Processing of Plutonium by Ion Exchange-VI. Plutonium (IV) Sorption Kinetics on Dowex $1 \times 4$ from Nitrate Solutions," Nucl. Appl. 2, 379-389 (1966), LA-DC-7066.

7. S. F. Marsh, "Recent Improvements in Plutonium Processing by Ion Exchange at Los Alamos," Tenth Annual Actinide Workshop, Los Alamos, New Mexico, May 13, 1986.

8. A. R. Kazanjian, D. C. Fisher, and M. D. Brown, "Anion Exchange Resin Evaluation," Rocky Flats Plant internal report PPC 86-083, September 12, 1986. 


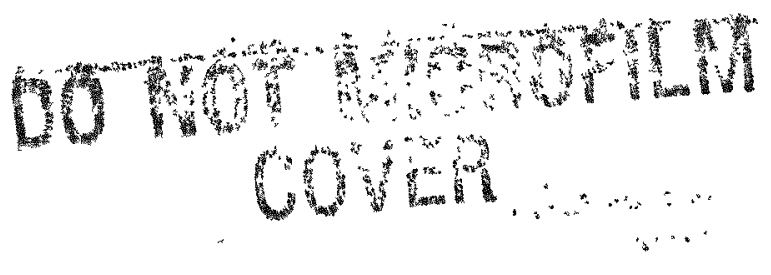

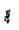

Printed in the United States of America

$$
\text { Available from }
$$

National Technical Information Service

US Department of Commerce

5285 Port Royal Road

Springfield, VA 22161

Microfiche (A01)

NTIS

Page Range Price Code

001-025

026050

$051-075$

076-100

101-125

$126-150$

A02
A03
A04
A05
A06
A07

$\mathrm{A} 03$

A04

A06

A07
NTIS

\begin{tabular}{cc} 
Page Range & $\begin{array}{c}\text { NTIS } \\
\text { Price Code }\end{array}$ \\
\hline $151-175$ & A08 \\
176200 & A09 \\
201225 & A 10 \\
226250 & A 11 \\
$251-275$ & A12 \\
276.300 & A13
\end{tabular}

NTIS

Page Range Price Code

301325

326. 350

$351-375$

376-400

401425

426-450
A14

A14

A 16

A 17

A 18

A.19

\begin{tabular}{cc} 
Page Range & $\begin{array}{c}\text { NTIS } \\
\text { Price Code }\end{array}$ \\
\hline 451475 & A20 \\
476500 & A21 \\
$501-525$ & A22 \\
$526-550$ & A23 \\
$551-575$ & A24 \\
$576-600$ & A25 \\
601 up $^{*}$ & A99
\end{tabular}

"Contact NTIS for a price quote. 